\title{
Analisis Strategi Pemasaran PT. Asar Mulia Sejahtera Dalam Menjual Peralatan Pengolahan Air Limbah
}

\author{
Arman Syah \\ Dosen Fakultas Ekonomi Universitas Pamulang \\ Ardaeng3s@yahoo.co.id
}

\begin{abstract}
ABSTRAK
Penulis melakukan penelitian ini pada PT. Asar Mulia Sejahtera . Tujuan penelitian untuk mengetahui strategi pemasaran yang tepat ditinjau dari segi Kekuatan, Kelemahan, Peluang dan Ancaman. Analisis SWOT yang digunakan yakni pendekatan secara kualitatif . Pendekatan kualitatif merupakan suatu analisis yang digunakan tanpa mempergunakan perhitungan angka-angka, melainkan berdasarkan penilaian atau pendapat serta dasar-dasar yang dapat menunjang dalam pengambilan keputusan yang bersifat subyektif. Berdasarkan analisis tersebut, alat yang digunakan untuk menyusun faktor-faktor strategis perusahaan adalah dengan menggunakan matrik SWOT Matrix.
\end{abstract}

Kata Kunci : Analisis SWOT, Strategi Pemasaran

\section{ABSTRACT}

The author conducted research at PT. Asar Mulia Sejahtera . The aim of research to find the right marketing strategy in terms of Strengths, Weaknesses, Opportunities and Threats. SWOT analysis used the qualitative approach. A qualitative approach is an analysis that is used without using the calculation of the figures, but based on ratings or opinions as well as the basics that can support decision-making is subjective. Based on this analysis, a tool used to draw up the strategic factors of the company is using the SWOT matrix.

The marketing strategy is more appropriate for PT. Asar Mulia Sejahtera is to increase the power of marketing, increasing promotional activities, improving customer service and developing facilities for the workshop as a means of supporting the manufacturing of the product so that quality and prices can be maintained

Key Words : SWOT Analysis, Marketing Strategy 


\section{Pendahuluan}

Bidang usaha pengolahan air limbah industri merupakan bidang yang menarik dan berkembang di Indonesia. Sektor ini merupakan peluang bisnis yang memiliki prospek cerah, lebih-lebih di Indonesia yang jumlah perkembangan industrinya sangat besar.

Pemerintah dalam hal ini Kementerian Lingkungan Hidup telah mengeluarkan kebijakan-kebijakan tentang lingkungan hidup umumnya dan pada khususnya pencemaran air dalam beberapa Peraturan Menteri, sebagai contoh adalah sebagai berikut :

1. Undang-Undang Nomor 32 Tahun 2009 tentang Perlindungan dan Pengelolaan Lingkungan Hidup

2. Peraturan Pemerintah Nomor 82 Tahun 2001 tentang Pengelolaan Kualitas Air dan Pengendalian Pencemaran Air

3. Peraturan Pemerintah Nomor 27 Tahun 2012 tentang Izin Lingkungan

4. Peraturan Menteri Lingkungan Hidup Republik Indonesia Nomor 5 Tahun 2014 tentang Baku Mutu Air Limbah

Dengan adanya peraturan pemerintah tersebut, maka pelaku pelaku baik kalangan industri maupun domestik ( Hotel, Apartemen, Mall, Rumah Sakit, dII) sebagai penghasil/pembuang air limbah tentunya diwajibkan untuk melakukan/membuat pengelolaan air limbah (Wastewater Treatment Plant) sebelum air limbah tersebut dialirkan ke lingkungan ( saluran kota dan Laut )

PT. Asar Mulia Sejahtera adalah salah satu perusahaan yang bergerak di bidang perencanaan dan pembuatan peralatan instalasi air limbah. Dalam menjual salah satu unsur kunci dalam persaingan diantara pelaku bisnis ini adalah selain harga jual juga yang terpenting pelayanan terhadap pelanggan/costumer sehingga dibutuhkan Manajemen Pemasaran yang baik. 
Menurut Dharmmesta dan Handoko, manajemen pemasaran adalah berbagai kegiatan pokok yang dilakukan oleh sebuah perusahaan untuk terus mempertahankan kelangsungan hidup perusahaannya, untuk kemudian berkembang, dan untuk mendapatkan laba atau keuntungan.

Menurut Philip Kotler, Pengertian manajemen pemasaran adalah proses perencanaan dan pelaksanaan pemikiran, penetapan harga, promosi serta penyaluran gagasan, barang dan jasa untuk menciptakan pertukaran anatar barang dan jasa yang memuaskan tujuan-tujuan individu dan organisasi.

Kotler, P.(1980), Marketing Management: Analysis, Planning, and Control.

Kesimpulan pengertian manajemen pemasaran dari pernyataan para ahli di atas ialah : Merupakan gabungan atau bauran strategi, yang pencakup proses, kreasi, hubungan, komunikasi, dan menciptakan nilai yang di tujukan kepada konsumen untuk memberikan pemenuhan kebutuhan dan kepuasan mereka dan bisa mendatangkan keuntungan bagi sebuah perusahaan yang menjalankan manajemen pemasaran tersebut.

\section{Rumusan Masalah}

Berdasarkan latar belakang penelitian yang telah diuraikan di atas, maka yang menjadi perumusan masalah dalam proposal penelitian ini adalah:

1. Bagaimana penerapan strategi pemasaran PT. Asar Mulia Sejahtera dalam menjual peralatan instalasi pengolahan air limbah

2. Bagaimana strategi pemasaran PT. Asar Mulia Sejahtera yang tepat dalam meningkatkan penjualan

\section{Metode Penelitian}

Vol. 1 No.1 / September 2018 
Dalam melakukan penelitian ini, penulis menggunakan metode penelitian kualitatif. Peneliti memilih metode kualitatif dikarenakan metode ini memiliki penekanan pada lingkungan yang alamiah (natural setting), induksi, flexible, pengalaman secara langsung (direct experience), kedalaman (indepth), menangkap arti (verstehen), keseluruhan (wholeness), partisipasi aktif dari partisipan dan penafsiran (interpretation).

\section{Analisis SWOT (Strengths, Weakness, Opportunities, Threats)}

Lingkungan mikro perusahaan merupakan unsur internal dari perusahaan yang terdiri dari manajerial perusahaan, kualitas produk, finansal perusahaan, kemampuan SDM dan teknologi yang digunakan. Lingkungan makro terdiri dari pemasok, pelanggan, pesaing, peraturan pemerintah, faktor budaya, sosial, ekonomi, dan faktor alam sekitar. Analisis dengan matrik SWOT dapat menggambarkan secara jelas bagaimana peluang dan ancaman sebagai faktor eksternal dapat disesuaikan dengan kekuatan dan peluang sebagai internal yang dimiliki perusahaan.

Matrik IE meembantu dalam hal analisis lebih lanjut. Sebelum membuat matrik IE, terlebih dahulu dilakukan analisis SWOT yang hasilnya dirangkum dalam tabel EFAS dan IFAS. Penerapan analisis SWOT dilakukan dengan mempertimbangkan kekuatan (strength) dan kelemahan (weakness) sebagai faktor internal serta peluang (opportunity) dan ancaman (threat) sebagai faktor eksternal yang dimiliki PT. Asar Mulia Sejahtera. Adapun langkah-langkah yang digunakan untuk menyusun EFAS dan IFAS adalah sebagai berikut :

1.

Identifikasi faktor-faktor sukses kunci utama baik internal maupun eksternal yang menjadi kekuatan dan kelemahan PT. Asar Mulia Sejahtera 
2.

Analisis kekuatan dan kelemahan PT. Asar Mulia Sejahtera yang meliputi bauran pemasaran yaitu: product, price, place, promotion, people, partnership.

3.

Analisis peluang dan ancaman lingkungan eksternal yang dihadapi PT. Asar Mulia Sejahtera meliputi: kompetisi, legal/hukum, ekonomi, teknologi, sosial budaya dan lingkungan alam.

4. Menentukan bobot dari faktor-faktor sukses kunci, pada tahap ini akan dilakukan pembobotan oleh responden, besarnya bobot menunjukkan strategis indikator variabel penentu terhadap keberhasilan PT. Asar Mulia Sejahtera, Variabel ini diberi bobot dengan angka dari 0.01 (kurang mempengaruhi) sampai dengan 0.99 (sangat mempengaruhi) sehingga jumlah bobot semua variabel adalah 1.00 (satu) atau 100 persen. Pemberian bobot merupakan penilaian oleh wisatawan tentang tingkat kepentingan terhadap variabel-variabel dari faktor-faktor internal pemasaran dan tentang tingkat kepentingan terhadap variabel-variabel dari faktor-faktor eksternal.

Menentukan nilai (rating) dari setiap faktor sukses kunci. Responden akan menilai setiap faktor sukses kunci dengan menggunakan skala likert lima tingkat, yaitu memberikan respon terhadap setiap pernyataan dengan memilih salah satu dari 5 pilihan yang bersifat berjenjang.

\section{Matriks Evaluasi Posisi dan Tindakan Strategis (Strategic Position and Action Evaluation-SPACE Matrix),}

Matriks SPACE adalah alat manajemen strategis yang berfokus pada perumusan strategi terutama yang terkait dengan posisi kompetitif organisasi. Matriks SPACE dapat digunakan sebagai dasar untuk analisis lainnya, seperti 
analisis SWOT, BCG model matriks, analisis industri, atau menilai alternatif strategis (IE matriks).

\section{Hasil dan Pembahasan}

Analisis Matrix IFAS (Internal Factors Analysis Summary)

Setelah mengetahui faktor-faktor internal dari PT. Asar Mulia Sejahtera, maka untiuk menentukan strategi yang tepat bagi perusahaan maka dibuatlah matrix IFAS,(Internal Factors Analysis Summary), yang digunakan untuk menganalisis faktor kekuatan (Strength)dan kelemahan (Weakness) yang dimiliki oleh PT. Asar Mulia Sejahtera sebagai berikut :

Tabel 1.

Internal Factor Analysis Summary (IFAS)

\begin{tabular}{|l|c|l|l|}
\hline \multicolumn{1}{|c|}{ Indikator } & Bobot & Rating & $\begin{array}{c}\text { Skor (Bobot x } \\
\text { Rating) }\end{array}$ \\
\hline Kekuatan : & 0,11 & 3,50 & 0,385 \\
1. Harga Produk & 0.12 & 3.20 & 0,384 \\
2. Kualitas Produk & 0,07 & 3,60 & 0,252 \\
3. Waktu/schedule kerja & 0,05 & 3.00 & 0,150 \\
4. Sumber Daya & 0,15 & 3,50 & 0,525 \\
Manusia & & & 1,696 \\
5. Pelayanan konsumen & 0,50 & \multicolumn{2}{|l}{} \\
\hline Sub Total 1 & & & \\
\end{tabular}


ISSN

\begin{tabular}{|l|l|l|l|}
\hline $\begin{array}{l}\text { Kelemahan } \\
\text { 1. Kegiatan Promosi - }\end{array}$ & 0,14 & $-3,00$ & $-0,420$ \\
2. Kekurangan tenaga \\
$\begin{array}{l}\text { Pemasaran } \\
\text { 3. Pangsa Pasar masih - } \\
\text { kurang }\end{array}$ & 0,05 & $-3,60$ & $-0,180$ \\
4. Transportasi & 0,03 & $-3,60$ & $-0,108$ \\
5. Kantor cabang & 0,02 & $-3,80$ & $-0,076$ \\
\hline Sub Total 2 & 0,50 & & $-1,564$ \\
\hline TOTAL IFAS & 1.00 & & 0,132 \\
\hline
\end{tabular}

Sumber : Pengolahan data penelitian.

Keterangan.

Bobot:

$$
\begin{array}{ll}
0.00-0,125 & =\text { Pengaruh kecil } \\
0.126-0,250 & =\text { Pengaruh sedang } \\
0.251-0,375 & =\text { Pengaruh besar } \\
0.376-0,500 & =\text { Pengaruh sangat besar }
\end{array}
$$

Rating pada matrik IFAS:

$$
\begin{aligned}
& 1=\text { Merupakan kelemahan Utama } \\
& 2=\text { Merupakan kelemahan kecil } \\
& 3=\text { Merupakan kekuatan kecil } \\
& 4=\text { Merupakan kekuatan Utama }
\end{aligned}
$$

\subsubsection{Analisis Matrix EFAS (Eksternal Factors Analysis Summary)}

Untuk lebih mudah mengetahui faktor-faktor eksternal dari PT. Asar Mulia Sejahtera, maka untiuk menentukan strategi yang tepat bagi 
perusahaan maka dibuatlah matrix EFAS, (Eksternal Factors Analysis Summary), yang digunakan untuk menganalisis faktor Peluang (Opportunity )dan ancaman (threats) yang dimiliki oleh PT. Asar Mulia Sejahtera sebagai berikut :

Tabel 2.

External Factor Analysis Summary (EFAS)

\begin{tabular}{|l|c|c|c|}
\hline \multicolumn{1}{|c|}{ Indikator } & Bobot & Rating & Skor (Bobot x Rating) \\
\hline \begin{tabular}{l} 
1. Perkembangan Industri \\
\multicolumn{1}{|c|}{ Dan Gedung- gedung }
\end{tabular} & 0,19 & 3,50 & 0,665 \\
2. Pengawasan Pemerintah & 0,08 & 3,00 & 0,240 \\
3. Daya Beli konsumen & 0,03 & 2,50 & 0,075 \\
4. Workshop & 0,15 & 3,50 & 0,525 \\
5. Dukungan Supplier & 0.05 & 2,60 & 0,130 \\
\hline Sub Total 1 & 0,50 & & 1,635 \\
\hline Ancaman & 0,14 & $-3,50$ & $-0,490$ \\
1. Munculnya Pesaing & 0,10 & $-3,00$ & $-0,300$ \\
2. Teknologi & 0,11 & $-2,80$ & $-0,308$ \\
3. Regulasi pemerintah & 0,09 & $-2,40$ & $-0,216$ \\
4. Produk luar Negeri & 0,06 & $-2,80$ & $-0,168$ \\
5. Kondisi Politik dan - & & & $-1,482$ \\
\hline Keamanan dalam negeri & & & \\
\hline Sub Total 2 & 0,50 & & \\
\hline & & & \\
\hline
\end{tabular}

Vol. 1 No.1 / September 2018 


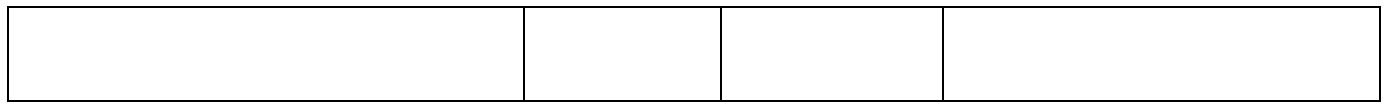

Sumber : Pengolahan data penelitian.

Keterangan

Bobot: $\quad 0.00-0,125=$ Pengaruh kecil

$$
\begin{array}{ll}
0.126-0,250 & =\text { Pengaruh sedang } \\
0.251-0,375 & =\text { Pengaruh besar } \\
0.376-0,500 & =\text { Pengaruh sangat besar }
\end{array}
$$

Rating pada matrik EFAS :

1 = Memiliki peluang yang sangat kecil dan ancaman yang sangat

besar

2 = Memiliki peluang yang kecil dan ancaman yang besar

3 = Memiliki peluang yang besar dan ancaman yang kecil

$4=$ Memiliki peluang yang sangat besar dan ancaman yang sangat

kecil

Berdasarkan hasil analisis internal perusahaan pada matrix IFAS diperoleh Nilai 0,132 (total skor Kekuatan 1.696 ditambah Nilai kelemahan 1,564), sedangkan analisis faktor Eksternal pada matrix EFAS diperoleh nilai 0,153 (total nilai peluang sebesar 1.635 ditambah nilai ancaman sebesar - 1,482). Maka dapat diketahui bahwa strategi pemasaran PT. Asar Mulia Sejahtera berada pada kuadran I. Strategi yang sesuai untuk perusahaan adalah strategi agresif, yaitu diperlukan perluasan dan memaksimalkan kekuatan internal dan eksternal pemasaran dapat melakukan strategi seperti pengembangan pasar, inovasi produk dan pengembangan produk. 
Berdasarkan penjelasan diatas maka dapat dibuat diagram SWOT sebagai berikut :

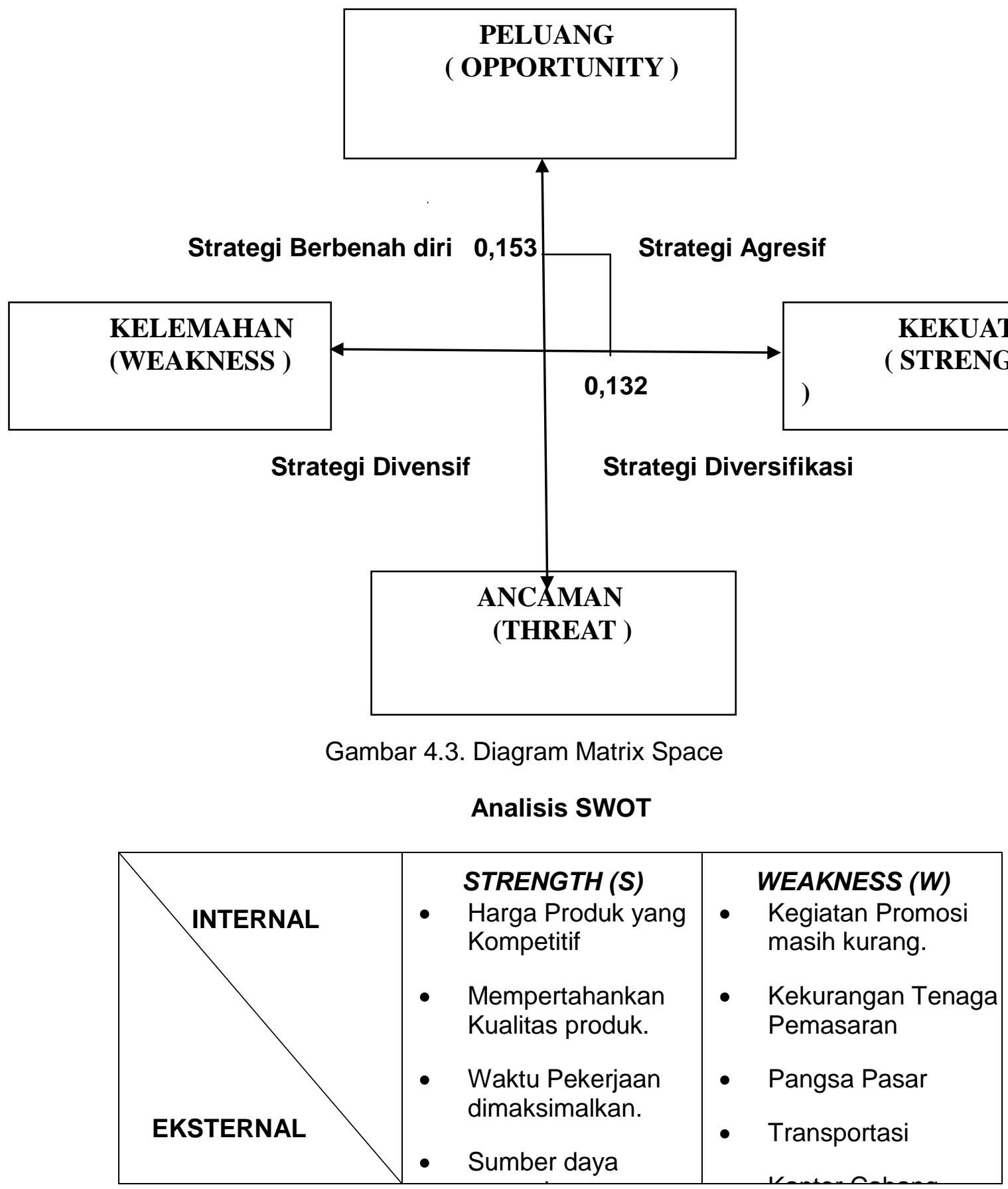

Vol. 1 No.1 / September 2018 


\begin{tabular}{|c|c|c|}
\hline $\begin{array}{l}\text { OPPORTUNITY(O) } \\
\text { - } \text { Pertumbuhan } \\
\text { Industri dan } \\
\text { Gedung } \\
\text { - } \begin{array}{l}\text { Pengawasan } \\
\text { Pemerintah }\end{array} \\
\text { - } \text { Daya Beli } \\
\text { Konsumen } \\
\text { - Workshop } \\
\text { Dukungan Supplier }\end{array}$ & 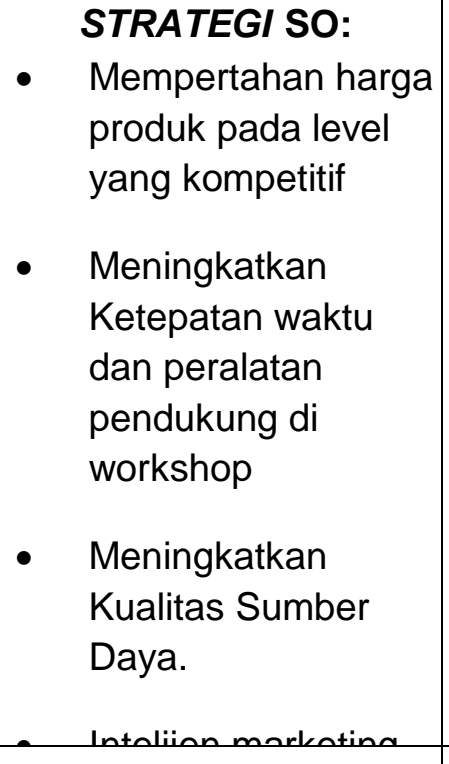 & $\begin{array}{l}\text { STRATEGI WO: } \\
\text { - } \quad \text { Mengembangkan } \\
\text { kegiatan promosi } \\
\text { - } \quad \text { Mengembangkan } \\
\text { kualitas dan } \\
\text { kuantitas tenaga } \\
\text { Pemasaran dan } \\
\text { Servis. } \\
\text { Menjalin kerjasama } \\
\text { dengan rekanan di } \\
\text { area industri } \\
\text { Membuka kantor } \\
\text { - } \\
\text { namanadidnarab }\end{array}$ \\
\hline $\begin{array}{ll} & \text { TREAT (T): } \\
\text { - } & \text { Munculnya } \\
\text { Pesaing } & \\
\text { - } & \text { Perkembangan } \\
& \text { Teknologi } \\
\text { - } & \text { Regulasi } \\
& \text { Pemerintah } \\
\text { - } & \text { Produk Luar Negeri } \\
\text { - } & \begin{array}{l}\text { Faktor politik dan } \\
\text { keamanan dalam } \\
\text { negeri }\end{array}\end{array}$ & $\begin{array}{l}\text { STRATEGI ST: } \\
\text { - } \text { Menjaga hubungan } \\
\text { yang erat dengan } \\
\text { prinsipal } \\
\text { - } \\
\text { Menjaga Kualitas } \\
\text { produk } \\
\text { - Mensiasati agar } \\
\text { harga produk bisa } \\
\text { bersaing dipasaran } \\
\text { Menjalin kerjasama } \\
\text { untuk kontrak servis }\end{array}$ & 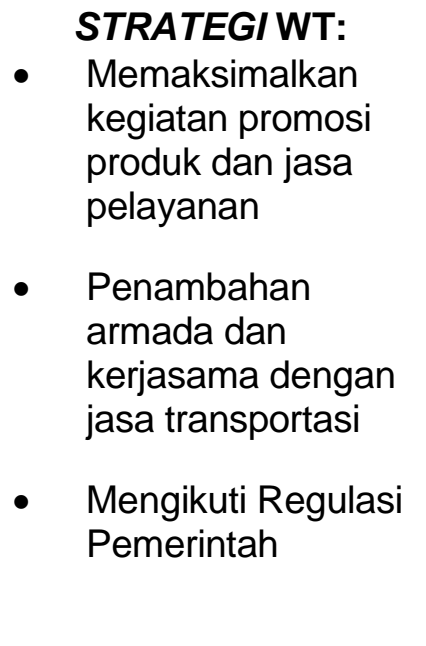 \\
\hline
\end{tabular}

Berdasarkan Matrik Space di atas ditunjukkan bahwa posisi perusahaan berada pada koordinat $(0.132-0.153)$. Hasil tersebut menggambarkan posisi strategis perusahaan berdasarkan analisis faktorfaktor strategis eksternal (EFAS) dan faktor-faktor strategis internal (IFAS) perusahaan yang dapat dilihat pada diagram SWOT, di mana posisi perusahaan berada dalam kuadran I yang mendukung strategi agresif / Ofensif atau pertumbuhan. Menurut Pearce dan robinson (1977) yang dikutip Anjang sari $(2014,6)$ merupakan strategi yang paling disukai dimana perusahaan menghadapi beberapa peluang lingkungan eksternal dan banyak Vol. 1 No.1 / September 2018 
kekuatan yang mendorong pemanfaatan peluang tersebut. Strategi ini menyarankan strategi yang berorientasi pada pertumbuhan untuk memanfaatkan situasi yang menguntungkan ini.

Strategi tepat untuk digunakan oleh PT. Asar Mulia Sejahtera adalah dengan mempertahankan kualitas produk serta peningkatan pelayanan, untuk merebut peluang terbesar yaitu kebutuhan industri dan daya beli konsumen pada industri-industri. Selain itu juga mengurangi kelemahan pada para pemasar yang kurang maksimal dan kegiatan promosi yang kurang,serta merubah ancaman menurunnya daya beli konsumen dan persaingan yang semakin ketat.

\section{Kesimpulan}

1. Strategi pemasaran yang dilaksanakan oleh PT.Asar Mulia Sejahtera saat ini untuk menjual peralatan pengolahan air limbah adalah :

- Memberikan pelayanan kepada konsumen terutama setelah penjualan/after sales

- Menjaga kualitas produk peralatan yang ditawarkan ke konsumen

- Memberikan harga yang kompetitir

2. Strategi pemarasan yang lebih tepat bagi PT. Asar Mulia Sejahtera adalah :

- Menambah tenaga pemasaran untuk mendapatkan konsumen yang baru 
- Meningkatkan kegiatan promosi

- Lebih meningkatkan pelayanan konsumen

- Mengembangkan sarana dan fasilitas workshop sebagai sarana penunjang fabrikasi produk agar kualitas dan harga dapat dipertahankan.

\section{Saran}

Sebagai kelanjutan dari kesimpulan di atas maka ada beberapa saran yang sebaiknya dilakukan oleh PT. Asar Mulia Sejahtera untuk meningkatkan volume penjualannya sebagai berikut :

1. Pengembangan produk (Product Development) dengan berusaha menawarkan produk yang berkualitas, baik dari segi model dan fungsi yang dukung dengan teknologi sehingga peralatan berfungsi dengan baik sesuai harapan konsumen

2. PT. Asar Mulia Sejahtera harus dapat memenuhi keinginan dan harapan dari pelanggan dalam hal kualitas, harga, keandalan produk, jaminan, respon dan cara pemecahan bila produk tidak maksimal atau terjadi kerusakan

\section{DAFTAR PUSTAKA}

Abbas Salim. 2007. Asuransi dan Manajemen Risiko. Jakarta: Raja Grafindo Persada

Afifuddin dan Beni Ahmad. 2009. Metodologi Penelitian Kualitatif. Bandung: Pustaka Setia.

Asubonteng, dkk, 1996, Servqual Reviseted : A Critical Review Of Service Quality. Journal Of Service Marketing, Vol 10

Buchari, Alma, 2004, Manajemen Pemasaran dan Pemasaran Jasa, Cetakan Keenam, Bandung : Alfabeta

Vol. 1 No.1 / September 2018 
Charles W. Lamb, Joseph F. Hair, Carl Mcdaniel. 2001. Pemasaran. Edisi Pertama, Jakarta : $\quad$ Salemba Empat

Daryanto, 2011, Sari Kuliah Manajemen Pemasaran, Bandung : Sarana Tutorial Nurani Sejahtera.

Denzin dan Lincoln, 2007, Metode Penelitian Kualitatif, Penerbit Rosda

Dharmesta, Basu Swastha, 2002, Azas-azas Marketing, Yogyakarta : Liberty , 2005, Manajemen Pemasaran Modern, Edisi Kedua, Yogyakarta : Liberty

Djam'an Satori dan Aan Komariah, 2009, Metode Penelitian Kualitatif, Bandung : Alfabeta,

Etta Mamang Sangadji \& Sopiah., 2013, Perilaku Konsumen, Yogjakarta : Penerbit Andi Offset.

Freddy Rangkuti, 2006, Riset Pemasaran, Jakarta : Gramedia Pustaka Utama

2006. Teknik Mengukur dan Strategi Meningkatkan Kepuasan Pelanggan. Jakarta : Penerbit PT Gramedia Pustaka Utama

2008, Analisis SWOT Teknis Membelah Kasus Bisnis, Jakarta : Gramedia Pustaka Utama

Hadari, Nawawi. 2005. Metode Penelitian Bidang Sosial. Yogyakarta: Gadjah Mada University Press

dan Martini, 2006, Instrumen Penelitian Bidang Sosial., Yogyakarta: Gadjah Mada University Press.

Hanan, Mack \& Karp, Peter, 1991, Customer Satisfaction: How to Maximize, Measureand Market your company's UltimateProduct. New York: American Management Association

Hasan, M. Iqbal, 2000, Pokok-pokok Materi Metodologi Penelitian dan Aplikasinya, Bogor: Ghalia

Husein Umar, 2010, Riset Pemasaran \& Perilaku Konsumen, cetakan kelima, Jakarta : PT. Gramedia Pustaka Utama

Irawan Handi, 2002. 10 Prinsip Kepuasan Pelanggan, Jakarta : PT. Elex Media Komputindo

J.R. Raco, 2010, Metode Penelitian Kualitatif : Jenis, Karakteristil dan Keunggulan, Jakarta: $\quad$ Grasindo

Jay Heizer \& Barry Render, 2009, Operations Management, Jakarta : Salemba Empat

Jhon A. Pearce \& Richard B. Robinson, 2014, Manajemen Strategi Buku1 Edisi 12, Jakarta : Salemba Empat

Vol. 1 No.1 / September 2018 
Jhon M. Bryson, 1999, Perencanaan Strategi, Jakarta : Pustaka Pelajar

Juanim, 2004, Analisis Jalur dalam Riset Pemasaran, Bandung : Universitas Pasundan Juran, J.M.1989.Juran on Leadership for Quality, The Free Press, MacMillan,Inc. E. Nugroho (penterjemah).1998. Kepemimpinan Mutu, Pustaka Binaman ressindo, Jakarta.

Kotler, Philip, 1997, Manajemen Pemasaran: Analisis, Perencanaan, Implementasi dan pengendalian Edisi kedelapan,terjemahan Arcella Ariwati Hermawan. Jakarta : Salemba Empat , 2005, Manajemen Pemasaran, Edisi Kesebelas,Jilid 1,Alih Bahasa Benyamin Molan, Jakarta: PT Indeks Kelompok Gramedia . 2008. Manajemen Pemasaran. Edisi Milenium Dua. Jakarta: PT.Indeks Kelompok Gramedia

Kotler,Philip dan Keller,Kevin Lane. 2009. Manajemen Pemasaran Edisi Ketiga belas Jilid 1, Jakarta : Penerbit Erlangga.

$\overline{\text { Education }}$ 2012. Marketing Management. Fourteenth Global Edition. Pearson

Kotler dan Armstrong, 1999, Principle Of Marketing 8 th Edition, New Jersey : Prentice Hall , (terjemahan Alexander Sindoro), 2001, Dasar - dasar Pemasaran, Jakarta : $\quad$ Prenhallindo

Kotler dan Armstrong, 2002, Manajemen Pemasaran, Jilid 2, Alih Bahasa oleh Hendra Teguh dkk, Edisi Milenium, Jakarta : PT Prenhallindo

Kotler dan Armstrong, 2000, Manajemen Pemasaran Indonesia, Alih Bahasa oleh Ancella Anitawati dan Hermawan, Edisi Pertama, Jakarta : Salemba Empat

Lamb, Charles. W., Jr., Joseph F. Hair Jr., dan Carl McDaniel, 2006, Pemasaran, Alih Bahasa oleh Octarevia, Edisi Kelima, Jakarta : Salemba Empat

Lovelock, Christopher, 1998. Service Marketing and Management. New Jersey:Prentice Hall.

Lupiyoadi, Rambat. 2001. Manajemen Pemasaran Jasa. Jakarta : PT. Salemba Empat. Michael E. Porter, 2007, Strategi Bersaing (Competitive Stategy) oleh Hendry, Tangerang : Kharisma Publishing Group

Moleong, Lexy J, 2008. Metodologi Penelitian Kualitatif, Bandung: PT. Remaja Rosdakarya. 
Parasuraman Zeitmal. 1988, Service Quality : A Conceptual Framework For Understanding e-implication for Future Researchand Managerial Practice : Msi Monograph New York.

Peter F. Drucker. 1979, Manajemen : Tugas, Tanggung Jawab, Praktek Buku 1 oleh Sitor Situmorang dkk, Jakarta : Gramedia

Poerwandari, E. Kristi. 1998. Metode Penelitian Sosial, Jakarta : Universitas Terbuka

Pranoto, I.S., 2012, Prinsip Desain Pengolahan Air Limbah Sistem Anaerob , Yogjakarta: PT.Biosan Mandiri

Prastowo, Andi. 2011. Metode Penelitian Kualitatif dalam Perspektif Rancangan Penelitian Jogjakarta: Ar-Ruzz Media.

, 2004, Metode Dan Teknik Menyusun Tesis, Bandung : CV. Alfabeta

Ratminto dan Atik Winarsih. 2005. Manajemen Pelayanan, Yogjakarta : Penerbit Pustaka Belajar,

Riduwan, 2014. Metode Dan Teknik Menyusun Proposal Penelitian, Bandung : Penerbit Alfabeta

Rhenald Kasali, 2011, Membidik Pasar Indonesia, Segmentasi, Targeting \& Positioning, Jakarta, Gramedia Pustaka Utama.

Ricky W. Griffin, 2002, Manajemen Jilid 1 alih bahasa Gina Gania, Jakarta : Erlangga

Saladin, Djaslim, 2003, Intisari Pemasaran dan Unsur-unsur Pemasaran, Cetakan Ketiga, Bandung : Linda Karya , 2006, Manajemen Pemasaran, Edisi Keempat, Bandung : Linda Karya

Simamora, Bilson, 2003, Riset Pemasaran, Jakarta : PT Gramedia Pustaka Utama

Sugiyono,2004, Metode Penelitian Bisnis, Bandung, Alfabetha .2008, Memahami Penelitian Kualitatif, Bandung : Alfabeta.

2001. Memenangkan Pasar Dengan Pemasaran Yang Efektif dan Profitable, Jakarta: PT. Gramedia Pustaka Utama.

T. Hani Handoko, 2011, Dasar - Dasar Manajemen Operasi Dan Produksi, Yokjakarta BPFE

Tjiptono, Fandy. 1997. Strategi Pemasaran. Yogyakarta: Penerbit Andi Offset 
Tjiptono, Fandy dan Gregorius Chandra, 2013, Pemasaran Strategik, Yogyakarta : Andi Offset

William J. Stanton, 1981, Fundamentals Of MarketingVol. 7, United States Of Amerika

Yin, Robert K, 2003. Studi Kasus Desain dan metode, Jakarta : Raja Grafindo Persada. 